expenditure (cinema-vans, \&c.). The paper is illustrated by lively pictograms showing the mass education year, phases of mass literacy work, the value of voluntary effort, and the relation between village leaders, local government staff, rural centres, and mass education teams.

\title{
Fort Hare Graduation
}

THE first graduation ceremony since Fort Hare Native College was affliated to Rhodes University was held at Fort Hare on 25 April, Dr. Alty, Principal and Vice-Chancellor of Rhodes University, presiding. The graduation address was delivered by Professor A. R. Radcliffe-Brown, formerly Professor of Social Anthropology at Oxford. In his address Professor Radcliffe-Brown referred to the responsibility attaching to privilege in social life, and urged those who had received the privilege of a university education to be awake to their social responsibilities and to use the education they had received for some advantage to their own people and the society in which they were placed. The most valuable thing to be learnt from any sort of education was to think and act in accordance with reason. 'However difficult it may be to cultivate reason in the world of today,' he said, 'it is worth while ... to make the attempt, and it should, I think, be the first function of a university to encourage and help all such attempts. The greatest enemy of reason is prejudice. The first requirement of the pursuit of reason is an open mind. . . If your education gives you this it gives you a precious possession.'

\section{Ecole Coloniale, Bruxelles}

L'Ecole coloniale a pour but de donner aux élèves réguliers, candidats à un emploi au service du Congo Belge et du Ruanda-Urundi, une formation spéciale en rapport avec les fonctions qu'ils auront à remplir. Elle comprend les sections suivantes:

I $^{0}$ La section Juridique, accessible aux docteurs en droit, admis comme candidats pour une place de magistrat de carrière;

$2^{\circ}$ La section générale Supérieure, accessible aux candidats à un emploi d'agent de la $3^{\circ}$ catégorie de l'Administration d'Afrique. Pour être admis à cette section les intéressés doivent être porteurs d'un diplôme universitaire obtenu après un cycle d'études complet de quatre années au moins.

$3^{\circ}$ La section générale Inférieure, accessible aux candidats à un emploi d'agent de la $4^{\circ}$ catégorie de l'Administration d'Afrique. Pour être admissible à cette section les candidats doivent notamment être porteurs d'un diplôme d'études moyennes complètes du degré supérieur.

$4^{\circ}$ La section de l'Enseignement, accessible aux candidats à un emploi dans le cadre du personnel des écoles officielles de l'administration d'Afrique. Elle intéresse les professeurs, instituteurs et institutrices, qui se destinent à l'enseignement officiel.

$5^{\circ}$ La section des Télécommunications, accessible aux candidats à un emploi dans le cadre des Télécommunications.

L'enseignement est gratuit. La durée des sessions est de 3 à 4 mois pour la section Juridique et les sections générales Supérieure et Inférieure; I mois (juillet-août) pour la section de l'Enseignement et 6 mois pour la section des Télécommunications.

\section{East African Institute of Social Research}

THE third Conference of the Institute took place at Kampala from I to 9 January 1952 . It took the form of a small meeting of Fellows which was mainly devoted to the discussion of 